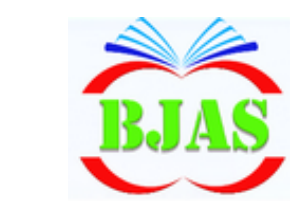

ISSN $1814-5868$
Available online at http://journal.bajas.edu.iq

https://doi.org/10.37077/25200860.2020.33.2.12

College of Agriculture, University of Basrah

Basrah J. Agric. Sci. 33(2): 138-146, 2020
Basrah Journal of Agricultural Sciences

\title{
Milk Lactoferrin: A Probable Immunological Agent Against SARS-CoV-2
}

\section{: A Review}

\author{
Jahanzaib Azhar ${ }^{1}$, Tahereh Mohammadabadi ${ }^{2}$, Masroor Ellahi Babar ${ }^{3}$ \& Tanveer Hussain $^{*}$ \\ ${ }^{1}$ Department of Biotechnology, Virtual University of Pakistan, Lahore, Pakistan. \\ ${ }^{2}$ Department of Animal Science, Faculty of Animal Science and Food Technology, Agricultural \\ Sciences and Natural Resources University of Khuzestan, Ahvaz, Iran \\ ${ }^{3}$ The University of Agriculture, Dera Ismail Khan, Khyber Pakhtunkhwa, Pakistan \\ ${ }^{4}$ Department of Molecular Biology, Virtual University of Pakistan, Lahore, Pakistan \\ *Corresponding author: tanveer.hussain@vu.edu.pk
}

Received 20 July 2020; Accepted 12 September 2020; Available online 20 October 2020

\begin{abstract}
In current COVID-19 pandemic, when there is no specific antiviral treatment and vaccine is available yet, many nutritional supplements have caught the attention to manage the disease. Lactoferrin is one of a natural nutritional supplement found in the milk of livestock mammals and has immunomodulation property due to its iron withholding ability and capacity to bind to multiple cellular receptors. The antiviral ability of lactoferrin has been evaluated against many viruses including SARS-CoV which is closely related to SARS-CoV-2 (causative agent of COVID-19). Furthermore, lactoferrin also possesses antiinflammatory efficacy and can inhibit the circulating inflammatory cytokines (e.g. Interferon $\gamma$, interleukin (IL-) 1B, IL-6, IL-12) and chemokines (CCL2 and CXCL10) which are reported to be present in higher levels in COVID-19 patients. A particular research about exploring the potential of lactoferrin against SARS-CoV-2 is highly demandable because lactoferrin might prevent the SARS-CoV-2 from infecting the host cells due to its biological activities regarding antiviral immunity. We are hopeful that further research on evaluating the pharmacological effect of lactoferrin against SARS-CoV-2 will signify its role to combat COVID-19.
\end{abstract}

Key words: Lactoferrin, SARS-CoV-2, COVID-19, Immunomodulation, Antiviral.

\section{Introduction}

The novel coronavirus disease (COVID-19), caused by SARS-CoV-2, has been rapidly spread to all over the world and created the global health crisis. The spike protein has been reported as a determinant of virus entry into the host cells via ACE2 receptor; Infected individ- uals represent mild to severe clinical manifestations of dry cough, fever, shortness of breath, bilateral pneumonia and some a typical symptoms including sore throat, diarrhoea and vomiting (Zhu et al., 2020). The infection can be spread through close contact with infected 


\section{Azhar et al. / Basrah J. Agric. Sci., 33(2): 138-146, 2020}

persons and respiratory droplets (Shereen $e t$ al., 2020). Many antiviral treatments are proposed but yet there is no properly established therapeutics to contain virus and vaccine development against the disease is in the human trial phase which may take some months or a year to make a breakthrough (Kuchler et al., 2020). The current methodology to control pandemic is to be confined in isolation, personal hygiene measures and taking immunity booster nutritional supplements.

In current situation, one should must be aware of immunity boosting specific food because nutrition is closely associated with immune system function and host resistance to infection. The existing evidences indicate that the supplementation of several nutrients can reduce the risk of viral infections and are correlated with positive impact on enhancing immunity (Jayawardena et al., 2020). These nutrients include vitamins, proteins, metabolites and probiotics which are vital for body's immune system working and strengthening. For immunity development, these components are shown to involve in $\mathrm{B}$ and $\mathrm{T}$ cells activation and their subsequent proliferation ( $\mathrm{Wu}$ et al., 2019). Moreover, they are also involved in inducing and modulating the both innate and adaptive immune response (Gombart et al., 2020). Hence the strong immunity through optimal nutrition is the only sustainable way to withstand COVID-19.

Dairy products from livestock animals especially milk and its proteins are considered to be beneficial for human health and the immune system (Al-Hatim et al., 2020). The existing epidemiological studies showed that consumption of cow and camel's milk is correlated with the lower prevalence of bacterial and viral infections (Claeys et al.,
2013). This clearly suggests that components (vitamins, globulins, glycoproteins and oligosaccharides) present in the milk of livestock animals may provide the immunity against microbial infections if taken in adequate amount (Loss et al., 2015). One of the important components is milk lactoferrin which is a multifunctional protein of the transferrin family.

Lactoferrin is a non-toxic globular glycoprotein that has been evident to provide protection against respiratory viruses including SARS-CoV (Lang et al., 2011) which is closely related to SARS-CoV-2 that is the etiological agent of COVID-19 (Chen et al., 2020). Recently, the immunoprotective and antiinflammatory property of lactoferrin has captured the immense interest in the scientific community to assess its potential against COVID-19 because of its dual capability to provoke the immune system to fight pathogen attack (Legrand \& Mazurier, 2010) and simultaneously preventing the inflammatory responses (Lepanto et al., 2019). To examine the potential of lactoferrin in immunoprotection against COVID-19, knowledge of its biology including structure, membrane receptors, immunomodulatory and antiviral mechanisms as well as sources is necessary. Thus, in the current review, we have explored the immunoprotective and antiviral mechanism of lactoferrin within the scope of its preventive and therapeutic applications against viruses and discussed the possible role of lactoferrin as an adjunct treatment for COVID-19.

\section{Sources and structural chemistry of Lactoferrin}

In 1939, Lactoferrin molecule was first identified and isolated from Bovine milk 


\section{Azhar et al. / Basrah J. Agric. Sci., 33(2): 138-146, 2020}

(Sorensen \& Sorensen, 1939) containing 689 amino acids (Moore et al., 1997). It is present in rich amount in milk and also regarded as a nutraceutical or act as a functional food. After its discovery and isolation from bovine milk, lactoferrin was also found and isolated in the milk of other livestock mammals including camel, sheep and goat (Conesa et al., 2008). Moreover, lactoferrin is also produced in the body by secondary granules of neutrophils and as a secretion by exocrine glands (Okubo et al., 2016). Our specific focus is on its source from animal milk because the lactoferrin present in animal milk and colostrum has more influence in immunomodulation and provide resistance to viral and bacterial infections (Iglesias-Figueroa et al., 2019).

A wide range of lactoferrin concentrations has been estimated in animal milk depending on milk yield, somatic cell count and stage of lactation. In bovine milk, the concentration of lactoferrin varies from $31.78 \mu \mathrm{g} . \mathrm{mL}^{-1}$ to 485.63 $\mu \mathrm{g} . \mathrm{mL}^{-1}$ depending on stage of lactation, parity of cow and somatic cell count (Cheng et al., 2008) but its concentration was found to be high in colostrum ranging between $1-5 \mathrm{mg} / \mathrm{mL}$ (Stelwagen et al., 2009). Furthermore, the concentration of lactoferrin in camel's milk was estimated to be 20-2100 $\mu \mathrm{g} . \mathrm{mL}^{-1}$ (Al-Majali et al., 2007) and has the highest antimicrobial activity (Conesa et al., 2008). Studies showed that camel milk lactoferrin varies widely in normal milk from 0.02 to $7.28 \mathrm{mg} \cdot \mathrm{mL}^{-1}$ but the maximum amount of lactoferrin $\left(2.3\right.$ g. $\left.\mathrm{L}^{-1}\right)$ was seen about 48 hours after parturition (El-Hatmi et al., 2007). Lactoferrin from bovine and human possess sequence homology and showed similar bioactivities which suggested the animal milk as a cheap lactoferrin supplement.
Three different isoforms of lactoferrin exist which include lactoferrin alpha (LF- $\alpha$ ), beta (LF- $\beta$ ) and gamma (LF- g). LF- $\alpha$ binds iron but the other two isoforms LF- $\beta$ and LF- $g$ are non-iron binding isoforms (Furmanski et al., 1989). In addition to iron, lactoferrin also binds many other metals including $\mathrm{Mn}_{2}{ }^{+}, \mathrm{Cu}_{2}{ }^{+}$and $\mathrm{Zn}_{2}{ }^{+}$(Berlutti et al., 2011). The polypeptide chain of lactoferrin contains 600-700 amino acid residues which vary according to the origin of the molecule. Protein structure is composed of $\alpha$-helix and $\beta$-sheets and further divided into two lobes including $\mathrm{N}^{-}$and $\mathrm{C}^{-}$lobe connected by 3-turn helix structure which gives extra flexibility to the protein (Anghel, 2014). The iron withholding capacity of lactoferrin is associated with its anti-microbial activity as well as in immunomodulation (Valenti \& Antonini, 2005).

\section{Biology of Lactoferrin membrane receptors}

Knowledge of the membrane receptors of lactoferrin is important to understand the mechanism of its biological activities as lactoferrin binds to multiple receptors which include Lactoferrin receptor, TLR2, TLR4 (Gao et al., 2018), CD14 (Rawat et al., 2012), Cytokine receptor (Takayama et al., 2017) and Intelectin-1 (Shin et al., 2008). All of these receptors are reported to be expressed on multiple types of cells and tissues including lymphocytes and intestinal epithelial cells (Suzuki et al., 2005). The capability of lactoferrin to bind to multiple receptors make it an important substance for antiviral immunity and host defence mechanism. Lactoferrin exerts its immunomodulatory activities by competing with infectious molecules or microbial particles for receptor occupancy thus inhibit the attachment of the particles (Kell et al., 2020). Interestingly, lactoferrin also binds to heparan 


\section{Azhar et al. / Basrah J. Agric. Sci., 33(2): 138-146, 2020}

sulfate proteoglycans (HSPGs) which is utilized by SARS-CoV and human coronavirus NL63 as a receptor for attachment and entry into the cell (Lang et al., 2011; Milewska et al., 2014). SARS-CoV-2 use ACE2 as its functional receptor but may bind to heparan sulfate proteoglycans (HSPGs) as SARS-CoV has been reported to utilize both receptors, yet no study has confirmed about the utilization of HSPGs by SARS-CoV-2 for its early attachment.

Epithelial cells are considered to be the first physical barrier to restrict the entry of harmful particles and have a role in innate immunity. Various milk components including lactoferrin have been shown to regulate the barrier functioning in which after cellular internalization, lactoferrin can induce differentiation and proliferation of epithelial cells (Liao et al., 2012). Another major component in cow's milk is transforming growth factor-beta (TGF $\beta$ ) which is also involved in the regulation of barrier functioning. Lactoferrin is involved in the intracellular cascade that leads to the production of endogenous TGF $\beta 1$ which further promotes the barrier functioning and strengthens it by regulating the expression of tight junctions (Perdijk et al., 2018). Thus the lactoferrin has diverse biological functions when it interacts with its membrane receptors.

\section{The immunomodulatory effects of Lactoferrin}

Lactoferrin (LF) has an important role in the immune system and host defence against infection and inflammation (Puddu et al., 2009). Some of its immunomodulatory effects are based on complexes with lipopolysaccharide (LPS). The lactoferrin binds to the same lipoproteins that the virus is bound to, and thus able to prevent the virus from attaching to the cell, but if the virus penetrates the cell, it prevents its replication by stimulating the killer immune cells like natural killer cells, granulocytes and macrophages (Valenti \& Antonini, 2005).

Lactoferrin can regulate the production of cytokines/chemokines, production of ROS and peroxides (Britigan et al., 2001), the recruitment, activation, differentiation, and proliferation of immune cells (Legrand \& Mazurier, 2010), particularly macrophages, neutrophils, basophils, eosinophils, mastocytes, and dendritic cells (Legrand, 2012). LF modulates the phagocyte capacity of cells and lytic activity through the recognition of specific binding sites (Legrand et al., 2006).

LF transported into the nucleus, binds to DNA (Gonzalez-Chavez et al., 2009; Queiroz et al., 2013) and activates different signaling pathways (Gonzalez-Chavez et al., 2009). The researchers concluded that LF shows antiinflammatory activity through the inhibition of pro-inflammatory cytokines such as interferongamma, tumor necrosis factor-alpha and interleukin (IL)-1, IL-2 and IL-6. Also at the cellular level, LF strengthens the recruitment of blood polymorph nuclear cells and stimulates the myelopoietic process (Gonzalez-Chavez et al., 2009). Also in chronic viraemia, lactoferrin promote a Th1 cytokine profile in peripheral blood (Ishii et al., 2003).

Lactoferricin derived from lactoferrin degradation limits initiation of the inflammatory cascade; enhances IL-10 production; thereby encouraging Th2 (antiinflammatory)-like activity. Lactoferrin interference appears mediated through fibroblast gene expression, modulating protein 
Azhar et al. / Basrah J. Agric. Sci., 33(2): 138-146, 2020

production and altering the extracellular matrix, thus modulating the motility of immune cells (Embleton et al., 2013).

\section{Antiviral effects of Lactoferrin}

Lactoferrin is primary defence factor against mucosal infections and cell surfaces, thus inhibiting microbial and viral adhesion and their entry into host cells by blocking of binding to heparan sulfate proteoglycan cell receptors and or by direct binding to host cells and or virus particles (Van der Strate et al., 2001; Berlutti et al., 2011). The cationic nature of lactoferrin and its capability for keeping iron at acidic condition of stomach and may be responsible for the binding ability to viral negative surface structures (Berlutti et al., 2011).

Lactoferrin prevents viral invasion of the host cells and avoiding the infection (Queiroz et al., 2013). The apo form of lactoferrin is shown to be more potent than the holo form, but the reasons for this have not been elucidated yet (Berlutti et al., 2011). The antiviral activity of lactoferrin is against both DNA and RNA viruses (Van der Strate et al., 2001), including rotavirus, respiratory syncytial virus, herpes viruses and HIV (Berlutti et al., 2011). The inhibiting activity of lactoferrin on viruses takes place in the early cycles of viral infection, rather than inhibiting virus replication after the cell infection (Orsi, 2004). Another group of researchers also reported that the property of lactoferrin to inhibit viral entry into the host cell is more significant than its ability of immunomodulation (Jenssen \& Hancock, 2009).

Lactoferrin showed importance as defence molecule of host and its physiological activities includes antibacterial, antiviral, antioxidant, anti-inflammatory, immunomodulatory, anticarcinogenic, antiprotozoan and antifungal (Gonzalez-Chavez et al., 2009). According to studies, iron withholding capability of lactoferrin is also effective in the modulation of motility of immune cells, and inhibition of biofilm formation of pathogenic microorganisms (Berlutti et al., 2011).

The antiviral activity of human Lf and bovine Lf against enveloped and naked viruses has been shown since 1994. In many research studies, when both types of lactoferrin and their isoforms (apo- and holo forms) were examined, no significant differences were observed in the antiviral effects of different forms (Berlutti et al., 2011). Both lactoferrins and their isoforms are effective in the early phase of the viral infection thus prevent virus entry into the host cell by blocking cellular receptors or binding to virus particles (Valenti \& Antonini, 2005). But Superti et al. (2008) indicated that bovine Lf has higher antiviral activity than human Lf.

\section{COVID-19 and Lactoferrin}

Control methods of COVID-19 pandemic are only containment and hygiene measures, while there are no antiviral treatments and vaccines yet. Its proposed nutritional supplements are useful against SARS-CoV-2 which causes COVID-19. Lactoferrin (Lf), as an anti-viral nutritional supplement has been studied against the broad range of viruses including SARS$\mathrm{CoV}$, and interestingly which is close to SARSCoV-2 (Chen et al., 2020). Furthermore, it has immunomodulatory and anti-inflammatory characteristics which can boost host immune responses to infections and prevent microbial infections (Bruni et al., 2016). Moreover, Lf inhibited the virus entry via binding to heparan sulfate proteoglycans (HSPGs) in the cell 
Azhar et al. / Basrah J. Agric. Sci., 33(2): 138-146, 2020

surface in murine coronavirus, and human coronaviruses hCOV-NL63 (Milewska et al., 2014) and pseudotyped SARS-CoV (Lang et al., 2011). Most (79\%) of sequences of the SARS-CoV and SARS-CoV-2 are identical, and their receptor-binding domain structure is also very similar (Peroni \& Fanos, 2020). But there are no published researches on Lf effects on SARS-CoV-2 entry into host cells.

In some patients, mortality from COVID-19 is not only due to viral infection but cytokine storm syndrome associated with hyperinflammation leads to acute respiratory distress and subsequently mortality (Mehta et al., 2020). In severe COVID-19 cases, increases in cytokines and acute phase reactants such as interleukin IL-6, tumor necrosis factor-a (TNFa) and ferritin happens. Lf can modulate an immune and inflammatory response to viral infection, so Lf could be a candidate for adjunct treatment for more severe cases of COVID-19.

\section{Conclusion}

Milk lactoferrin as an important nutritional supplement is effective against viral attacks by binding specifically to many virus particles or viral receptors, boosting the immune system. Furthermore, Lf with unique properties of immunomodulatory, anti-inflammatory and antiviral may have precious potential as a preventative and adjunct treatment for COVID19 as it involves both viral infection and immune responses of host. But it needs further researches and development on Lf nutritional supplementation on SAR-CoV-2.

\section{Acknowledgements}

The authors gratefully acknowledge the experts who have given insights and suggestions for writing this article.

\section{Conflict of interest}

The authors declare that there is no conflict of interest.

\section{ORCID}

J. Azhar : 0000-0002-2210-1422

T. Mohammadabadi: 0000-0002-8250-6704

M.E. Babar: 0000-0001-6417-6222

T. Hussain:0000-0002-2522-2406

\section{References}

Al-Hatim, R. R., Al-Rikabi, A. K., \& Ghadban, A. K. (2020). The Physico-chemical properties of bovine and buffalo whey proteins milk by using ultrafiltration membrane Technology. Basrah Journal of Agricultural Sciences, 33, 122-134. https://doi.org/10.37077/25200860.2020.33.1.10

Al-Majali, A. M., Ismail, Z. B., Al-Hami, Y., \& Nour, A. Y. (2007). Lactoferrin concentration in milk from camels (Camelus dromedarius) with and without subclinical mastitis. International Journal of Applied Research in Veterinary Medicine, 5, 120. http://jarvm.com/articles/Vol5Iss3/

Anghel, L. (2014). Lactoferrin: analysis of the structure profile. Chemistry Journal of Moldova, 9, 99-106. https://doi.org/10.19261/cjm.2014.09(2).14.

Berlutti, F., Pantanella, F., Natalizi, T., Frioni, A., Paesano, R., Polimeni, A., \& Valenti, P. (2011). Antiviral properties of lactoferrin- A natural immunity molecule. Molecules, 16, 6992-7018. https://doi.org/10.3390/molecules16086992.

Britigan, B. E., Lewis, T. S., Waldschmidt, M., McCormick, M. L., \& Krieg, A. M. (2001). Lactoferrin binds CpG-containing oligonucleotides and inhibits their immunostimulatory effects on human B cells. The Journal of Immunology, 167, 2921-2928.

https://doi.org/10.4049/jimmunol.167.5.2921

Bruni, N., Capucchio, M. T., Biasibetti, E., Pessione, E., Cirrincione, S., Giraudo, L., Corona, A., \& Dosio, F. (2016). Antimicrobial activity of lactoferrin-related peptides and applications in human and veterinary medicine. Molecules (Basel, Switzerland), 21. https://doi.org/10.3390/molecules21060752 


\section{Azhar et al. / Basrah J. Agric. Sci., 33(2): 138-146, 2020}

Cheng, J. B., Wang, J. Q., Bu, D. P., Liu, G. L., Zhang, C. G., Wei, H. Y., Zhou, L. Y., \& Wang, J. Z. (2008). Factors affecting the lactoferrin concentration in bovine milk. Journal of Dairy Science, 91, 970-976. https://doi.org/10.3168/jds.2007-0689

Chen, Y., Liu, Q., \& Guo, D. (2020). Emerging coronaviruses: genome structure, replication, and pathogenesis. Journal of Medical Virology, 92, 418423. https://doi.org/10.1002/jmv.25681

Claeys, W. L., Cardoen, S., Daube, G., De Block, J., Dewettinck, K., Dierick, K., \& Vandenplas, Y. (2013). Raw or heated cow milk consumption: Review of risks and benefits. Food Control, 31, 251262. https://doi.org/10.1016/j.foodcont.2012.09.035

Conesa, C., Sánchez, L., Rota, C., Pérez, M. D., Calvo, M., Farnaud, S., \& Evans, R. W. (2008). Isolation of lactoferrin from milk of different species: calorimetric and antimicrobial studies. Comparative Biochemistry and Physiology Part B: Biochemistry and Molecular Biology, 150, 131-139. https://doi.org/10.1016/j.cbpb.2008.02.005

El-Hatmi, H., Girardet, J., Gaillard, J., Yahyaoui, M. H., \& Attia, H. (2007). Characterization of whey proteins of camel (Camelus dromedarius) milk and colostrum. Small Ruminant Research, 70, 267-271. https://doi.org/10.1016/j.smallrumres.2006.04.001

Embleton, N., D., Berrington, J. E., Chris, W. M., \& Cummings, S. S. (2013). Lactoferrin: Antimicrobial activity and therapeutic potential. Seminars in Fetal \& Neonatal Medicine, 18, 143-149. https://doi.org/10.1016/j.siny.2013.02.001

Furmanski, P., Li, Z. P., Fortuna, M. B., Swamy, C. V., \& Das, M. R. (1989). Multiple molecular forms of human lactoferrin. Identification of a class of lactoferrins that possess ribonuclease activity and lack iron-binding capacity. Journal of Experimental Medicine, $\quad 170, \quad 415-429$. https://doi.org/10.1084/jem.170.2.415

Gao, C. H., Dong, H. L., Tai, L., \& Gao, X. M. (2018). Lactoferrin-containing immunocomplexes drive the conversion of human macrophages from M2-into M1like phenotype. Frontiers in Immunology, 9, 37. https://doi.org/10.3389/fimmu.2018.00037

Gonzalez-Chavez, S.A., Arevalo-Gallegos, S., \& RasconCruz, Q. (2009). Lactoferrin: structure, function and applications. International Journal of Antimicrobial Agents, 33, 301-308. https://doi.org/10.1016/j.ijantimicag.2008.07.020

Gombart, A. F., Pierre, A., \& Maggini, S. (2020). A Review of micronutrients and the immune systemworking in harmony to reduce the risk of infection. Nutrients, 12, 236. https://doi.org/10.3390/nu12010236

Iglesias-Figueroa, B. F., Espinoza-Sánchez, E. A., Siqueiros-Cendón, T. S., \& Rascón-Cruz, Q. (2019). Lactoferrin as a nutraceutical protein from milk, an overview. International Dairy Journal, 89, 37-41. https://doi.org/10.1016/j.idairyj.2018.09.004

Ishii, K, Takamura, N., \& Shinohara, M. (2003). Longterm follow-up of chronic hepatitis $\mathrm{C}$ patients treated with oral lactoferrin for 12 months. Hepatology Research, 25, 226e33. https://doi.org/10.1016/s13866346(02)00279-6

Jayawardena, R., Sooriyaarachchi, P., Chourdakis, M., Jeewandara, C., \& Ranasinghe, P. (2020). Enhancing immunity in viral infections, with special emphasis on COVID-19: A review. Diabetes \& Metabolic Syndrome, $\quad 14, \quad 367-382$. https://doi.org/10.1016/j.dsx.2020.04.015.

Jenssen, H., \& Hancock. R. E. W. (2009). Antimicrobial properties of lactoferrin. Biochimie, 91, 19-29. https://doi.org/10.1016/j.biochi.2008.05.015

Kell, D. B., Heyden, E. L., \& Pretorius, E. (2020). The Biology of Lactoferrin, an iron-binding protein that can help defend against viruses and bacteria. Frontiers in Immunology, 11, 1221. https://doi.org/10.3389/fimmu.2020.01221

Kuchler, H., Cookson, C., \& Neville, S. (2020). The \$2 bn race to find a vaccine. Financial Times, 7. https://www.ft.com/content/e0ecc6b6-5d43-11eab0ab-339c2307bcd4

Lang, J., Yang, N., Deng, J., Liu, K., Yang, P., Zhang, G., \& Jiang, C. (2011). Inhibition of SARS pseudovirus cell entry by lactoferrin binding to heparan sulfate proteoglycans. PLoS one, 6 e23710. https://doi.org/10.1371/journal.pone.0023710

Legrand, D., Elass, E., Carpentier, M., \& Mazurier, J. (2006). Interactions of lactoferrin with cells involved 


\section{Azhar et al. / Basrah J. Agric. Sci., 33(2): 138-146, 2020}

in immune function. Biochemistry and Cell Biology, 84: 282-290. https://doi.org/10.1139/o06-045

Legrand, D. (2012). Lactoferrin, a key molecule in immune and inflammatory processes. Biochemistry and Cell Biology, 90, 252-268. https://www.nrcresearchpress.com/doi/abs/10.1139/o $11-056$

Legrand, D., \& Mazurier, J. (2010). A critical review of the roles of host lactoferrin in immunity. Biometals, 23, 365-376. https://doi.org/10.1007/s10534-0109297-1

Lepanto, M. S., Rosa, L., Paesano, R., Valenti, P., \& Cutone, A. (2019). Lactoferrin in aseptic and septic inflammation. Molecules, 24, 1323. https://doi.org/10.3390/molecules24071323

Liao, Y., Jiang, R., \& Lönnerdal, B. (2012). Biochemical and molecular impacts of lactoferrin on small intestinal growth and development during early life. Biochemistry and Cell Biology, 90, 476-484. https://doi.org/10.1139/o11-075

Loss, G., Depner, M., Ulfman, L. H., Van Neerven, R. J., Hose, A. J., Genuneit, J., \& Weber, J. (2015). Consumption of unprocessed cow's milk protects infants from common respiratory infections. Journal of Allergy and Clinical Immunology, 135, 56-62. https://doi.org/10.1016/j.jaci.2014.08.044

Mehta, P., McAuley, D. F., Brown, M., Sanchez, E., Tattersall, R. S., \& Manson, J. J. (2020). Across Specialty Collaboration, U. COVID-19: Consider cytokine storm syndromes and immunosuppression. The Lancet, 395, 10331034.https://doi.org/10.1016/s0140-6736(20)30628-0

Milewska, A., Zarebski, M., Nowak, P., Stozek, K., Potempa, J., \& Pyrc, K. (2014). Human coronavirus NL63 utilizes heparan sulfate proteoglycans for attachment to target cells. Journal of Virology, 88, 13221-13230. https://doi.org/10.1128/jvi.02078-14

Moore, S. A., Anderson, B. F., Groom, C. R., Haridas, M., \& Baker, E. N. (1997). Three-dimensional structure of diferric bovine lactoferrin at $2.8 \AA$ resolution. Journal of Molecular Biology, 274, 222236. https://doi.org/10.2210/pdb1blf/pdb

Okubo, K., Kamiya, M., Urano, Y., Nishi, H., Herter, J. M., Mayadas, T., \& Kurosawa, M. (2016).
Lactoferrin suppresses neutrophil extracellular traps release in inflammation. E BioMedicine, 10, 204-215. https://doi.org/10.1016/j.ebiom.2016.07.012

Orsi, N. (2004). The antimicrobial activity of lactoferrin: Current status and perspectives. Biometals, 17, 189196. https://doi.org/10.1023/b:biom.0000027691.86757.e2

Puddu, P., Valenti, P., \& Gessani, S. (2009). Immunomodulatory effects of lactoferrin on antigen presenting cells. Biochimie, 91, 11-18. https://doi.org/10.1016/j.biochi.2008.05.005

Perdijk, O., van Splunter, M., Savelkoul, H. F., Brugman, S., \& van Neerven, R. J. (2018). Cow's milk and immune function in the respiratory tract: Potential mechanisms. Frontiers in Immunology, 9, 143. https://doi.org/10.3389/fimmu.2018.00143

Queiroz, V. A. O., Assis, A. M. O., \& Júnior, H. C. R. (2013). Protective effect of human lactoferrin in the gastrointestinal tract. Revista Paulista de Pediatria, 31, 90-95. https://doi.org/10.1590/s010305822013000100015

Rawat, P., Kumar, S., Sheokand, N., Raje, C. I., \& Raje, M. (2012). The multifunctional glycolytic protein glyceraldehyde-3-phosphate dehydrogenase (GAPDH) is a novel macrophage lactoferrin receptor. Biochemistry and Cell Biology, 90, 329-338. https://doi.org/10.1139/o11-058

Shereen, M. A., Khan, S., Kazmi, A., Bashir, N., \& Siddique, R. (2020). COVID-19 infection: Origin, transmission, and characteristics of human coronaviruses. Journal of Advanced Research, 94, 9198. https://doi.org/10.1016/j.jare.2020.03.005

Shin, K., Wakabayashi, H., Yamauchi, K., Yaeshima, T., \& Iwatsuki, K. (2008). Recombinant human intelectin binds bovine lactoferrin and its peptides. Biological and Pharmaceutical Bulletin, 31, 1605-1608. https://doi.org/10.1248/bpb.31.1605

Sorensen, M., \& Sorensen, S. (1939). Compte rendu des Travaux du Laboratoire de Carlsberg. The Proteins in Whey, 83, 432. https://doi.org/10.3406/crai.1939.85865.Stelwagen, K., Carpenter, E., Haigh, B., Hodgkinson, A., \& Wheeler, T. T. (2009). Immune components of bovine colostrum and milk. Journal of Animal 


\section{Azhar et al. / Basrah J. Agric. Sci., 33(2): 138-146, 2020}

Science, 87, 3-9. https://doi.org/10.2527/jas.20081377

Superti, F., Berlutti, F., Paesano, R., \& Valenti, P. (2008). Structure and activity of lactoferrin -A multifunctional protective agent for human health. 1-32. In Fuchs, H., (Ed.). Iron Metabolism and Disease; Research Signpost: Kerala.

Suzuki, Y. A., Lopez, V., \& Lönnerdal, B. (2005). Lactoferrin. Cellular and Molecular Life Sciences, 62, 2560. https://doi.org/10.1007/s00018-005-5371-1

Takayama, Y., Aoki, R., Uchida, R., Tajima, A., \& AokiYoshida, A. (2017). Role of CXC chemokine receptor type 4 as a lactoferrin receptor. Biochemistry and Cell Biology, 95, 57-63. https://doi.org/10.1139/bcb-20160039

Valenti, P., \& Antonini, G. (2005). Lactoferrin: an important host defence against microbial and viral attack. Cellular and Molecular Life Sciences, 62, 2576-2587. https://doi.org/10.1007/s00018-005-53720

Van der Strate, W. A., Beljaars, L., Molema, G., Harmsen, M. C., \& Meijer D. K. F. (2001). Antiviral activities of lactoferrin. Antiviral Research, 52, 225239. https://doi.org/10.1016/s0166-3542(01)00195-4

Wu, D., Lewis, E. D., Pae, M., \& Meydani, S. N. (2019). Nutritional modulation of immune function: analysis of evidence, mechanisms, and clinical relevance. Frontiers in Immunology, 9, 3160. https://doi.org/10.3389/fimmu.2018.03160

Zhu, N., Zhang, D., Wang, W., Li, X., Yang, B., Song, J., \& Niu, P. (2020). A novel coronavirus from patients with pneumonia in China, 2019. New England Journal of Medicine, 382, 727-733. https://doi.org/10.1056/nejmoa2001017

\section{مقالة مرجعية: لاكتوفيرين الحليب: الفعالية المناعية المحتملة ضد فايروس سارس Cov-2}

جاهانزيب ازهر 1، طاهره محمدابادي، الهام مسرور بابار3 و تانفير حسين4

1 1 قسم التقنيات الحياتية، الجامعة التطبيقية الباكستانية، لاهور، باكستان

$2{ }^{2}$ قسم علوم الحيوان، كلية علوم الحياة والتقنيات الغذائية جامعة خوزستان للعلوم الزراعية والثروات الطبيعية، اهواز ، ايران

3

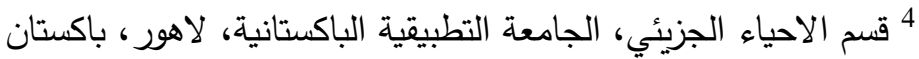

الملخص: خلال جائحة كورونا الحالية، ومع عدم وجود علاج أو لقاح للتعامل مع الفايروس المسبب للمرض، نالت المكائ المكملات الغذائية

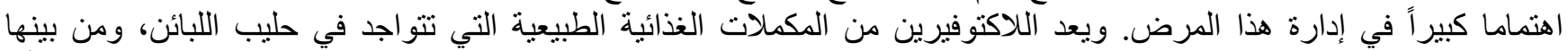

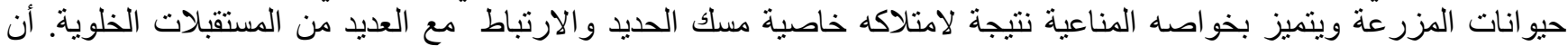

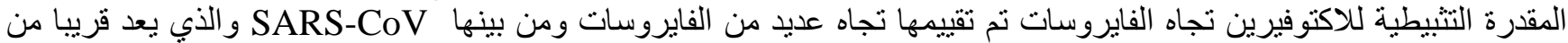
الفايروس الممرض SARS-Cov2 فضلاً عن دور اللاكتوفيرين كعامل مضاد للالتهابات مما يشكل عاملا مهما في تنثيط

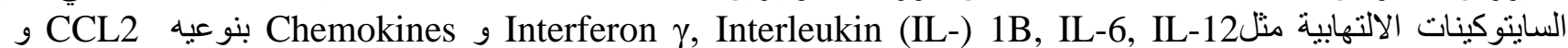
هالتي سجلت بمعدلات عالية جداً في مرضى كوفيد-19. أن أهمية در اسة اللاكتوفيرين تجاه SARS-CoV

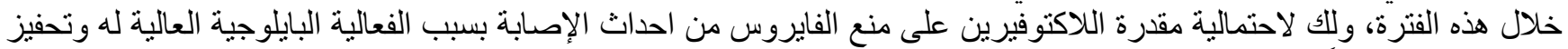
المناعة. ونأمل قريباً أن تتم تغطية الفعالية العلاجية و المناعية للاكتوفيرين تجاه

$$
\text { الكلمات المفتاحية: لاكتوفيرين، فايروس سارس كوفيد 2، تحفيز مناعي، مضاد فايروسي. }
$$

